\title{
EVALUASI KESESUAIAN PENULISAN RESEP PASIEN NON BPJS RAWAT JALAN DENGAN FORMULARIUM RUMAH SAKIT ISLAM BOGOR PERIODE OKTOBER - DESEMBER 2019
}

\author{
Binar Nursanti $1^{1 *}$, Yulia Heryani $2^{1}$ \\ ${ }^{1}$ Program Studi Diploma 3 (D3) Farmasi Sekolah Tinggi Teknologi Industri dan Farmasi, Bogor \\ ${ }^{2}$ Rumah Sakit Islam Bogor * \\ Korespondensi: binar09@yahoo.co.id
}

\begin{abstract}
ABSTRAK
Layanan farmasi rumah sakit merupakan bagian integral dari sistem medis rumah sakit yang berfokus pada perawatan pasien, pemberian obat yang berkualitas, dan pelayanan farmasi klinis yang terjangkau untuk semua lapisan masyarakat. Tujuan dari penelitian ini adalah untuk mengetahui kelayakan resep non-BPJS untuk pasien rawat jalan menggunakan formularium Rumah Sakit Islam Bogor antara bulan Oktober dan Desember 2019. Penelitian ini bersifat deskriptif dan data diambil dari kumpulan resep kemudian dianalisis. Jika obat yang diresepkan termasuk dalam resep rumah sakit, penggunaan obat dianggap sesuai dengan resep. Hasil penelitian menunjukkan kesesuaian peresepan resep berdasarkan jenis obat $(98,79 \%)$ dan peresepan $(96,55 \%)$. Hasil penelitian menyimpulkan pada tahun 2008 kepatuhan obat terhadap peraturan rumah sakit belum memenuhi standar pelayanan minimal rumah sakit (100\%) dan perlu dievaluasi untuk memenuhi peresepan dapat dilaksanakan Menurut formularium rumah sakit, sesuai standar pelayanan minimal rumah sakit tahun 2008 .
\end{abstract}

Kata Kunci: Pelayanan Farmasi, Formularium Rumah Sakit, Resep non BPJS, dan Resep Rawat Jalan.

\begin{abstract}
Hospital pharmacy services are an integral part of the hospital medical system that focuses on patient care, quality drug delivery, and affordable clinical pharmacy services for all levels of society. The purpose of this study was to determine the feasibility of non-BPJS prescriptions for outpatients using the Bogor Islamic Hospital formulary between October and December 2019. This study was descriptive in nature and the data was taken from a collection of prescriptions and then analyzed. If the prescribed drug is included in a hospital prescription, the use of the drug is considered according to the prescription. The results showed the suitability of prescribing based on the type of drug $(98.79 \%)$ and prescription $(96.55 \%)$. The results of the study concluded that in 2008 drug compliance with hospital regulations did not meet the hospital's minimum service standard (100\%) and needed to be evaluated to meet the prescription that it could be carried out according to the hospital's minimum service standard since 2008, according to the hospital formulary.
\end{abstract}

Keywords: Pharmacy Services, Hospital Formularies, Non BPJS Prescriptions, and Outpatient Prescriptions. 


\section{PENDAHULUAN}

Sesuai dengan Peraturan Menteri Kesehatan RI No. 4 tahun 2008 tentang kewajiban rumah sakit dan kewajiban pasien. Rumah Sakit adalah fasilitas kesehatan yang memberikan pelayanan medis yang lengkap sebagai bagian dari pelayanan rawat inap, rawat jalan, dan gawat darurat. Apoteker yang memberikan pelayanan kefarmasian di rumah

sakit harus memenuhi ketentuan Pasal 7 Permenkes No. 72 Tahun 2016.

Layanan obat di rumah sakit merupakan bagian integral dari sistem pelayanan rumah sakit yang berfokus pada pelayanan pasien dan memberikan obat yang bermutu, termasuk pelayanan farmasi klinik yang terjangkau di semua bidang (Permenkes2016). Menurut Organisasi Kesehatan Dunia (WHO, 2004), peresepan yang tepat mendorong penggunaan obat yang rasional dan memungkinkan pasien untuk menerima dosis obat yang tepat dengan biaya rendah untuk jangka waktu yang tepat sesuai dengan kebutuhan klinis mereka sesuai dengan Permenkes No. 129/Menkes/SK/II/2008 Republik Indonesia tentang Standar Minimal Pelayanan Rumah Sakit, Termasuk Waktu Tunggu untuk obat siap Pakai dan racikan. Standar resep sesuai formularium adalah $100 \%$.

Formulir rumah sakit adalah daftar obatobatan yang telah disetujui oleh tenaga medis, dievaluasi oleh apoteker dan terapis, dan diputuskan oleh manajemen rumah sakit. Formularium rumah sakit harus dievaluasi secara teratur sesuai dengan kebijakan dan kepentingan rumah sakit. Untuk meningkatkan kepatuhan formularium rumah sakit, rumah sakit perlu mempersiapkan penambahan dan penghapusan obat ke formularium rumah sakit berdasarkan indikasi ganda, efikasi, risiko, dan pertimbangan biaya (Permenkes RI, 2016, hlm.16).

Formularium rumah sakit dibuat dengan mengacu pada formulir negara/nasional. Pembuatan dan revisi roster rumah sakit dikembangkan dari perspektif terapeutik dan ekonomi dari penggunaan obat untuk selalu menerapkan formularium rumah sakit terkini untuk memenuhi kebutuhan perawatan yang wajar (Permenkes RI, 2016), hlm. 15).

Pemilihan obat yang tepat dalam sistem peresepan rumah sakit memiliki banyak manfaat, antara lain peningkatan kualitas obat untuk menekan biaya dan terwujudnya pelayanan medis yang efisien dan efektif. Standar Pelayanan Rumah Sakit Islam masih menggunakan standar pelayanan terendah yang dikeluarkan oleh Menteri Kesehatan Republik Indonesia pada tahun 2008. Standar ini menjadi tolak ukur pelayanan medis rumah sakit. Obat yang tidak diresepkan sesuai resep rumah sakit

dapat menurunkan kualitas pelayanan rumah sakit sehingga menimbulkan biaya tambahan dan waktu tunggu yang lama bagi pasien untuk menerima obat.

Berdasarkan penelitian sebelumnya di Rumah Sakit Umum Islam "X" tahun 2016, ditunjukkan kesesuaian peresepan resep dengan formularium berdasarkan jenis obat $(96,79 \%)$ (Zakiyah, 2016). Penelitian lain yang dilakukan di RSUD Kefamenanu pada tahun 2017 menunjukkan kesesuaian pembuatan resep menggunakan formularium berdasarkan lembar resep $(81,69 \%)$ dan jenis obat $(94,84 \%)$ (Yane, 2017).

Dari data di atas, penulis ingin mengevaluasi kecukupan resep untuk melihat apakah ada obat yang di luar dari formularium yang ada.

\section{METODE PENELITIAN}

Jenis survei ini adalah survei deskriptif yang melibatkan pengumpulan data secara retroaktif. Populasi penelitian ini terdiri dari 4.235 formulir resep dari resep non-BPJS rawat jalan di RS Islam Bogor dari bulan Oktober sampai Desember 2019. Penelitian ini menggunakan teknik dokumentasi untuk analisis data. Yaitu kepatuhan pengumpulan resep bulan Oktober, November dan Desember 2019, menginvestigasi resep secara tepat, mendukung dan menambah kredibilitas dan bukti kejadian, serta penulisan resep yang disajikan kedalam bentuk tabel, dan tingkat kepatuhan ditentukan dengan menghitung tingkat kepatuhan berdasarkan item obat.

\section{PROSEDUR PENGUMPULAN DATA}

Untuk mendapatkan data yang efektif dan akuntabel, Anda perlu mengumpulkan data yang sesuai dengan masalah dan subjek penelitian Anda. Penelitian ini menggunakan metode terdokumentasi untuk analisis data, metode pengumpulan resep untuk Oktober, November, dan Desember 2019, dan kemudian menyiapkan resep dengan baik untuk mendukung dan melengkapi keyakinan dan bukti dari kejadian tersebut. 
Dengan cara ini, peneliti dapat memperoleh informasi dan data dari dokumen, termasuk berbagai sumber tertulis, dalam bentuk jurnal dan juga bisa mendapatkan informasi dan hal lain yang terkait dengan penyusunan data dalam bentuk laporan, sesuai dengan kebutuhan analisis..

\section{HASIL DAN PEMBAHASAN HASIL Formularium Rumah Sakit}

RS. Islam Bogor adalah rumah sakit milik yayasan yang bernama YARSIB (Yayasan Rumah Sakit Islam Bogor) di Jl. Perdana Raya, Kecamatan Tanah sareal, Kota Bogor. Rumah sakit Islam Bogor belum memiliki standar minimal pelayanan rumah sakit yang khusus ditetapkan oleh rumah sakit, sehingga akan tetap menerapkan standar pelayanan Rumah Sakit minimum yang dikeluarkan oleh Menteri Kesehatan Republik Indonesia tahun 2008. Namun, RS Islam memiliki standar pelayanan operasional untuk kegiatan kefarmasian dan terapi yaitu :

\section{Rapat Tim Farmasi dan Terapi}

2. Penambahan Obat dalam Formularium Rumah Sakit

3. Penghapusan Obat dari Formularium Rumah Sakit.

Terdapat pedoman penggunaan obat di rumah sakit islam bertujuan untuk efisiensi dan peningkatan mutu pelayanan di rumah sakit berbasis pelayanan kefarmasian yang efektif di rumah sakit untuk profesional kesehatan, terutama dokter.

\section{KESESUAIAN RESEP DENGAN FORMULARIUM RUMAH SAKIT}

Kajian ketepatan resep menggunakan formularium rumah sakit ini dilakukan untuk pasien rawat jalan non-BPJS di RS Islam Bogor antara bulan Oktober sampai Desember 2019.

Jika dokter mengeluarkan resep untuk obat yang termasuk dalam formularium rumah sakit, maka resep tersebut dianggap sesuai formularium. Resep penelitian ini mengambil sebanyak 4.235 lembar resep. Dalam 4.235 lembar resep berisi 12.826 item obat.

Kesesuaian resep berdasarkan resep

$$
\% \text { Kesesuaian }=\frac{\text { Jumlah lembar resep sesuai formularium }}{\text { Jumlah lembar resepyang ditulis }} \times 100 \%
$$

Keterangan : Jumlah resep adalah total resep yang tercantum nama obat yang ditulis oleh dokter sesuai formularium rumah sakit Islam.

Jika resep obat berisi satu atau lebih obat yang tidak termasuk dalam formularium rumah sakit,

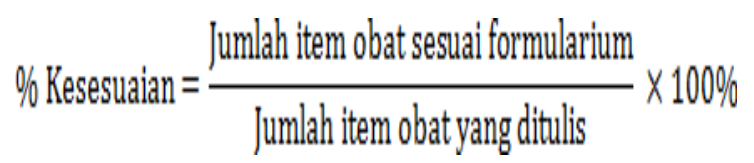

resep tersebut dianggap tidak sesuai dengan formularium. Dalam survei ini, jumlah resep dari Oktober hingga Desember 2019 sebanyak 4.235, jumlah resep yang sesuai sebanyak 4.089, dan tidak sesuai sebanyak 146 resep.

Kesesuaian resep berdasarkan item obat

Keterangan: Jumlah item obat ialah jumlah item Obat yang sesuai dengan Formularium Rumah Sakit Islam.

Jika resep yang ditulis dokter dimasukkan dalam formularium rumah sakit, maka resep itu akan diterapkan sesuai dengan formularium rumah sakit. 
56 Binar Nursanti et al., (Evaluasi Kesesuaian Penulisan Resep Pasien Non BPJS ...)

Tabel 1. Persentase Kesesuaian Resep Berdasarkan Item Obat Periode Oktober-Desember 2019

\begin{tabular}{lccccc}
\hline No & Bulan & Jumlah & Jumlah & Jumlah Item & \% Kesesuaian \\
& & Item & Item Obat & Obat Yang & Dengan \\
& & Obat & Yang & Tidak & Formulairum \\
& & Sesuai & Sesuai & RS \\
\hline 1 & Oktober & 4.318 & 4.268 & 50 & $98,84 \%$ \\
2 & November & 4.214 & 4.162 & 52 & $98,77 \%$ \\
3 & Desember & 4.294 & 4.241 & 53 & $98,77 \%$ \\
\hline \multicolumn{7}{r}{ Total } & 12.826 & 12.671 & 155 & \\
\hline & & & & \\
\hline
\end{tabular}

Tabel 1 menunjukkan bahwa persentase kepatuhan regulasi terkait farmasi berfluktuasi antara Oktober dan Desember 2019. (98,77\% 98,84\%) Persentase tertinggi yang dicapai pada bulan Oktober $(98,84 \%)$ adalah total obat yang sesuai dengan 4.268 obat dan 50 obat yang tidak sesuai dengan formularium. Persentase kepatuhan resep berbasis obat periode Oktober-
Desember 2019 adalah Rp. (98,79\%). Hal ini menunjukkan bahwa pengelolaan obat di fasilitas apotek RS Islam Bogor sudah sangat baik. Namun jika dilihat dari jumlah selisih obat yang mencapai 155 , artinya cukup banyak resep yang tidak sesuai formularium rumah sakit.

\section{Tabel 2. Persentase Kesesuaian Resep Berdasarkan Lembar Resep Periode} Oktober-Desember 2019

\begin{tabular}{|c|c|c|c|c|c|}
\hline \multirow[t]{3}{*}{ No } & \multirow[t]{3}{*}{ Bulan } & Jumlah & Jumlah & Jumlah lembar & $\%$ Kesesuaian \\
\hline & & lembar & lembar R/ & Tidak & Dengan \\
\hline & & $\mathrm{R} /$ & Sesuai & Sesuai & Formulairum RS \\
\hline 1 & Oktober & 1.451 & 1.404 & 47 & $96,76 \%$ \\
\hline 2 & November & 1.415 & 1.365 & 50 & $96,47 \%$ \\
\hline \multirow[t]{3}{*}{3} & Desember & 1.369 & 1.320 & 49 & $96,42 \%$ \\
\hline & Total & 4.235 & 4.089 & 146 & \\
\hline & Rata-rata & & & & $96,55 \%$ \\
\hline
\end{tabular}

Dari Tabel 2 terlihat bahwa tingkat kepatuhan resep berdasarkan lembar resep dari bulan Oktober hingga Desember 2019 adalah $96,42 \%$ hingga $96,76 \%$, yang merupakan tingkat tertinggi $(96,79 \%)$ pada resep di bulan Oktober. Persentase pemenuhan resep berdasarkan lembar resep periode OktoberDesember 2019 adalah $(96,55 \%)$. 


\section{PEMBAHASAN}

Evaluasi kesesuaian penggunaan obat terhadap formularium. Dari hasil yang diperoleh menunjukkan bahwa resep yang ditulis oleh dokter tidak sesuai dengan Keputusan Menteri Kesehatan Nomor 129/Menkes/SK/II/2008 tentang Standar Pelayanan Minimal Rumah Sakit yaitu 100\%.

Poliklinik tingkat kepatuhan paling rendah dalam menuliskan resep periode OktoberDesember 2019 adalah poliklinik umum sebanyak 40 obat. Adanya penulisan resep yang tidak sesuai dengan formularium rumah sakit berdasarkan Standar Pelayanan Minimal Rumah Sakit akan berdampak terhadap (Manalu, 2012):

a. Adanya kekosongan, kekurangan, dan obatobatan yang berlebih akan mempengaruhi persediaan obat.

b. Diperlukan lebih banyak investasi untuk memenuhi lebih banyak jenis obat.

d. Karena kekosongan persediaan obat, kualitas pelayanan obat akan sangat lama, dan penggantian obat akan terjadi sehingga akan mempengaruhi harga obat.

Pengadaan obat di farmasi RS. Islam Bogor sudah tercukupi, namun jika obat yang diresepkan dokter tidak ada dalam formularium, dokter dapat mengisi proposal pengadaan obat untuk menyarankan pembelian obat tersebut. Formulir tersebut diberikan kepada direktur rumah sakit, yang memutuskan apakah akan menerima

pembelian obat yang diusulkan. Saran ini juga akan dipertimbangkan dalam revisi formularium berikutnya.

Instalasi Farmasi di RS Islam Bogor telah menetapkan standar operasional terkait resep yang dikeluarkan oleh dokter, antara lain: Jika seorang dokter menulis resep di luar resep, dokter yang menulis resep tersebut menegaskan bahwa resep tersebut tidak mengandung obat yang tercantum dalam formularium, lalu memberi penawaran untuk obat dengan kandungan bahan aktif yang sama. Untuk obat yang tidak termasuk dalam resep tetapi sangat dibutuhkan oleh dokter yang meresepkan, apotek akan membeli obat yang sesuai dengan kebutuhan dokter dan memasukkannya ke dalam revisi formularium berikutnya. Menanggapi kebutuhan rumah sakit, formularim rumah sakit islam telah direvisi mengikuti revisi formulir nasional.

\section{SIMPULAN}

Bedasarkan.hasil.dari.penelitian.ini.dapat. disimpulkan:

a. Jumlah resep yang dianggap sesuai dengan formularium jika obat yang ada dalam resep tercantum dalam formularium rumah sakit. Dalam penelitian jumlah resep yang diambil yaitu sebanyak 4.235 lembar. Di dalam 4.235 lembar resep terdapat 12.826 item obat.

b. Persentase kepatuhan peresepan pasien non BPJS berdasarkan pengobatan periode Oktober-Desember 2019 adalah (98,79\%).

c. Persentase kepatuhan resep pasien non BPJS berdasarkan resep periode OktoberDesember sebesar $(96,55 \%)$.

d. Hasil persentase kesesuaian resep Rumah Sakit Islam Bogor belum memenuhi standar pelayanan minimal rumah sakit.

\section{DAFTAR PUSTAKA}

[1] Departemen Kesehatan Republik Indonesia. 2008. Keputusan Menteri Kesehatan Republik Indonesia, Nomor 129/Menkes/SK/II/2008 tentang Standar Pelayanan Minimal Farmasi di Rumah Sakit. Jakarta: Departemen Kesehatan Republik Indonesia.

[2] Dewan Perwakilan Rakyat. 2009. UndangUndang Republik Indonesia Nomor 4 tahun 2009 tentang Rumah Sakit. Jakarta: Dewan Perwakilan Rakyat Republik Indonesia dan Presiden Republik Indonesia.

[3] Hanifa, Zakiyah Nurul. 2017. Evaluasi Kesesuaian Peresepan Obat pada Pasien Umum Rawat Jalan dengan Formularium RSUI "X” periode januari-Maret 2016. Surakarta: Universitas Muhammadiyah.

[4] Kementrian Kesehatan RI. 2016. Peraturan Menteri Kesehatan Republik Indonesia Nomor 72 tahun 2016 tentang Standar Pelayanan Kefarmasian di Rumah Sakit. Jakarta: Kementrian Kesehatan Republik Indonesia.

[5] Kementrian Kesehatan RI. 2018. Peraturan Menteri Kesehatan Republik Indonesia Nomor 4 tahun 2018 Tentang Kewajiban Rumah Sakit dan kewajiban pasien. 
58 Binar Nursanti et al., (Evaluasi Kesesuaian Penulisan Resep Pasien Non BPJS ...)

Jakarta: Kementerian Kesehatan Republik Indonesia.

[6] Manalu D.D. 2012. Analisis Kepatuhan Dokter Organik Terhadap Formulairum di Rumah Sakit MH Thamrin Salemba pada Bulan Januari-Juli 2011, Skripsi, Fakultas Kesehatan Masyarakat Peminatan Manajeman Rumah Sakit. Depok: Universitas Indonesia.

[7] Siregar, Ch. J. P., Amelia, L. 2004. Farmasi Rumah Sakit, Teori dan Penerapan.Hal 90-91. Jakarta: Buku Kedokteran EGC.

[8] Wakhid Budiantoro, Ikhsanudin. 2017. Evaluasi Kesesuaian Peresepan Pasien Rawat Inap terhadap Formularium di RSUD Karanganyar tahun 2016. Surakarta: Universitas Muhammadiyah.

[9] World Health Organization. 2004. The World Medicine Situation. Geneve: WHO. 